\title{
Pedogenic approach to resolving the geomorphic evolution of the Pakua river terraces in central Taiwan
}

\author{
Heng Tsai ${ }^{a, *}$, Zeng-Yei Hseu ${ }^{b}$, Wen-Shu Huang ${ }^{a}$, Zueng-Sang Chen ${ }^{c}$ \\ a Department of Geography, National Changhua University of Education, No. 1, Chinte Road, Changhua 50007, Taiwan \\ ${ }^{\mathrm{b}}$ Department of Environmental Science and Engineering, National Pingtung University of Science and Technology, Pingtung 91201, TAIWAN \\ ${ }^{c}$ Department of Agricultural Chemistry, National Taiwan University, Taipei 10617, Taiwan
}

Received 13 May 2005; received in revised form 24 May 2006; accepted 19 June 2006

Available online 1 August 2006

\begin{abstract}
The southern part of the Pakua tableland in Taiwan comprises a series of wide, unpaired river terraces that have as many as six altitude levels, from PK-1 (highest) to PK-6 (lowest). The terrace surfaces are covered with lateritic soils. This study described, sampled and analyzed the soils from each terrace. Soil taxonomies are Oxisol, Ultisol and Inceptisol. Soil morphological characteristics were quantified as a profile development index (PDI) to determine the degree of soil development. The chemical analyses included cation exchange capacity (CEC) and selected extraction of Fe in soils. Based on the degree of soil development, surface deposits on terrace flights form the post-incisive soil chronosequence, supporting the hypothesis of terrace formation by fluvial processes. Soil ages were estimated based on iron crystallinity $\left(\mathrm{Fe}_{\mathrm{d}}-\mathrm{Fe}_{\mathrm{o}}\right) / \mathrm{Fe}_{\mathrm{t}}$. Analytical results indicate that river terraces in the Pakua tableland are aged 40-400 ka. The long-term uplift rate of the tableland can be estimated using terrace ages and folding geometry. The variation of uplift rates demonstrates that the landscape underwent increased shortening of frontal thrusting by the Changhua Fault running beneath the tableland.
\end{abstract}

(C) 2006 Elsevier B.V. All rights reserved.

Keywords: Pakua tableland; River terrace; Profile development index (PDI); Soil chronosequence; Iron crystallinity; Changhua Fault

\section{Introduction}

Taiwan has experienced oblique convergence of the Eurasian plate and Philippine Sea plate since roughly 5-7 Ma (Suppe, 1981; Angelier, 1986; Tsai, 1986; Ho, 1988; Kao and Chen, 2000) (Fig. 1A). Tectonic compression from the east produced a sequential westverging thrust-and-fold belt in west central Taiwan

\footnotetext{
* Corresponding author. Tel.: +886 47232105 2819; fax: +8864 7211186.

E-mail address: geotsaih@cc.ncue.edu.tw (H. Tsai).
}

(Fig. 1B). The Pakua tableland comprises a frontal deformation as an anticline in the thrust-and-fold belt (Lee et al., 1996; Deffontaines et al., 1997). The southern part of the tableland comprises a series of wide and unpaired terraces developed by the Choushui River and its tributaries (Fig. 2) (Shih and Yang, 1985). All terrace surfaces tilt eastward, probably due to a slipping Changhua Fault running beneath the tableland (Lee et al., 1996; Delcaillau et al., 1998; Mouthereau et al., 1999; Delcaillau, 2001). Consequently, these river terraces are excellent geomorphic markers for measuring differential and absolute deformation. Unfortunately, this geomorphic approach is limited by the lack of 


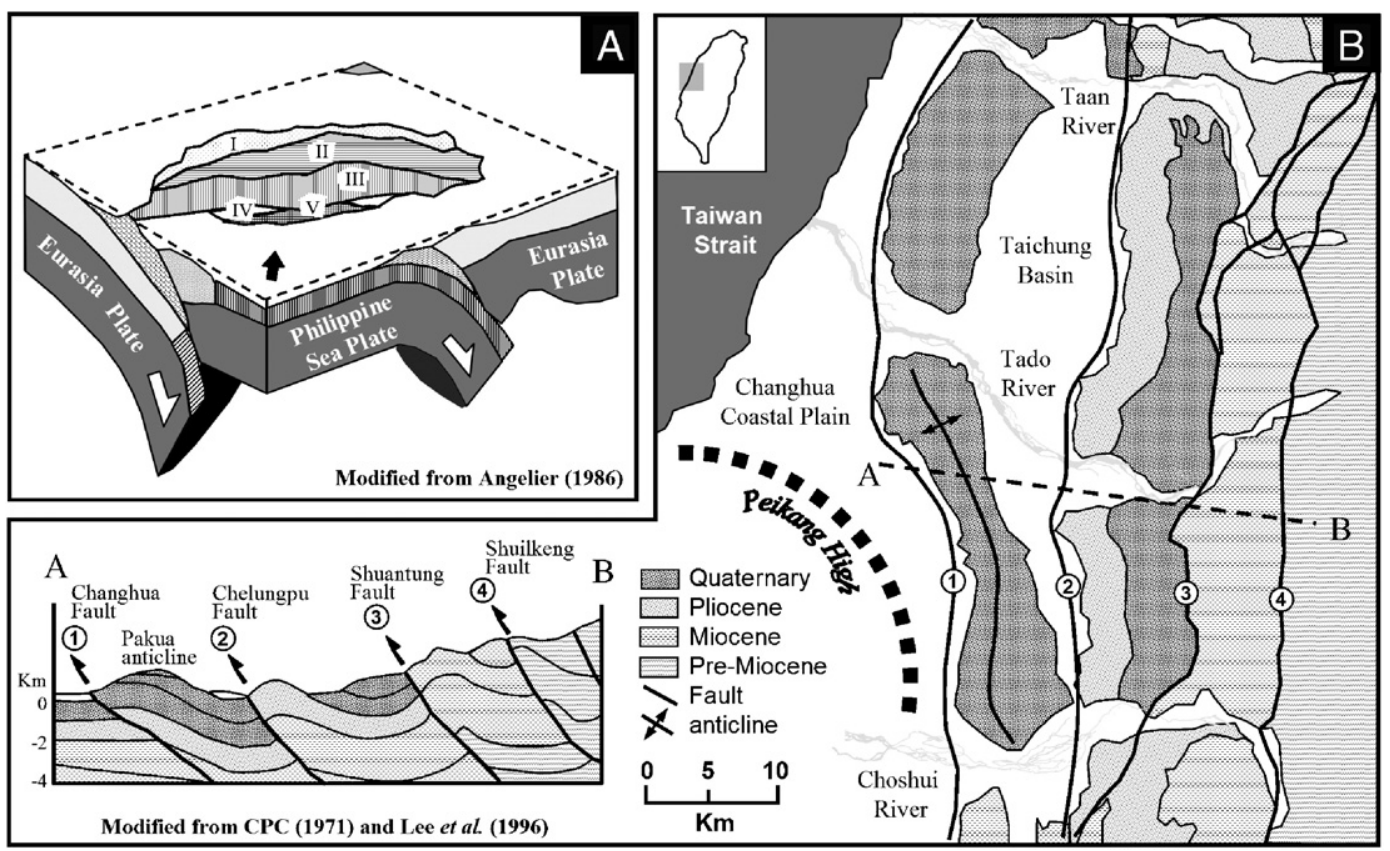

Fig. 1. (A) The general tectonic setting of Taiwan. Due to the subduction between the Eurasian plate and the Philippine Sea plate, the onshore Taiwan is divided into five geologic provinces: $\mathrm{I}=$ Coastal Plain; $\mathrm{II}=$ Western Foothills; III=Central Range; VI=Longitudinal Valley (the plate suture); $\mathrm{V}=$ Coastal Range (belonging to an arc-trench system of the Philippine Sea plate). (B) The geologic map of the Western Foothills and the crosssection along the dashed line shown in the map.

well-documented ages for the surfaces. Clearly, alternative chronologies are required to unravel the complex neotectonics of this area.

Soils have demonstrated utility for subdividing and correlating Quaternary successions (Morrison, 1968; Leamy et al., 1973; Mulcahy and Churchward, 1973; Birkeland, 1984; Tsai et al., 2006). Jenny (1941) indicated that most soil properties are time-dependent variables including, and not limited to, clay accumulation (Birkeland, 1999), accumulation of calcium carbonate $\left(\mathrm{CaCO}_{3}\right)($ Gile et al., 1966), and iron (Fe) oxide content and composition (Alexander, 1974; MacFadden and Hendricks, 1985; Maejima et al., 2002). Quantitative indices using a single value to evaluate the degree of soil development have been proposed (Bilzi and Ciolkosz, 1977; Torrent et al., 1980; Harden, 1982). Harden's (1982) profile development index (PDI), which quantifies field properties of soils, has proved to be an easy and effective approach for studying soil development rates and for quantitatively comparing soil development of different parent materials and in different climatic regimes (Harden and Taylor, 1983). For instance, Bockheim et al. (1992) found that late Quaternary marine terraces located along the Oregon coast can be differentiated using PDIs derived from field descriptions. Alonso et al. (1994), who examined seven fluvial terrace soils located along the
Almar river in Spain, found that the index values increased as soil age and degree of differentiation between the horizons of each soil became progressively evident.

Bull (1990) proposed that the soil sciences and fluvial geomorphology meet on river terrace flights that rise like stairs above active channels. The Pakua tableland river terraces form a chronosequence that allows facilitates the study of the rate and direction of soil development and landscape evolution. This study attempts to apply pedology to resolve the factors controlling the geomorphic evolution of terraces in the Pakua tableland. In this study, the weighted mean PDI (or WPDI) and the amounts of $\mathrm{Fe}$ and $\mathrm{Al}$ in soils are examined and compared with those obtained other studies to estimate soils and/or river terrace ages in the Pakua tableland. Moreover, landscape evolution and active tectonic deformation of the study area are discussed based on the pedogenic processes.

\section{Study area}

\subsection{Geology}

Taiwan is located at the convergent boundary between the Philippine Sea plate and the continental margin of the Eurasian plate. The Philippine Sea plate subducts beneath 


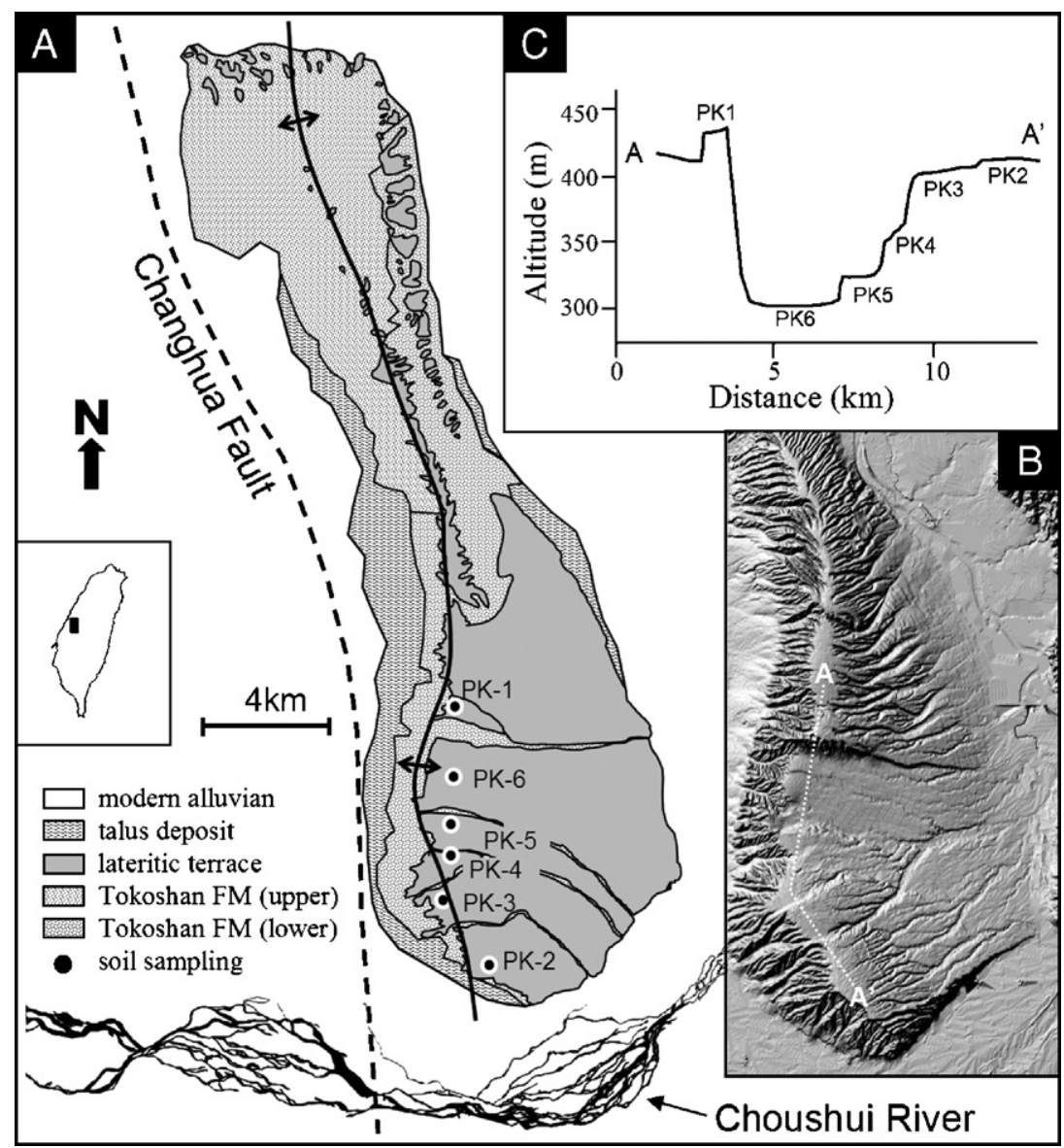

Fig. 2. The general geology and the distribution of river terraces on the Pakua tableland.

the Eurasian plate offshore eastern Taiwan, and overrides the South China Sea floor of the Eurasian plate south of Taiwan (Suppe, 1981; Tsai, 1986; Angelier, 1986; Ho, 1988) (Fig. 1). This oblique plate convergence is ongoing (Seno et al., 1993; Yu et al., 1997). Tectonic activity is manifested in continual crustal shortening and widespread seismic activities. Recent GPS data indicate a crustal shortening by $8.5 \mathrm{~cm} /$ year across the $200 \mathrm{~km}$ wide island (Yu et al., 1997). A series of subparallel thrust faults exist that results from the frontal thrust migrating westward by tectonics compression during the PlioPleistocene (Lee et al., 1996).

The Pakua tableland, about $30 \mathrm{~km}$ long and 5-10 km wide, is bound by the Changhua Fault to the west and

Table 1

Geographic information for soil classification

\begin{tabular}{lllllll}
\hline Pedon & $\begin{array}{l}\text { Slope } \\
(\%)\end{array}$ & Aspect & $\begin{array}{l}\text { Elevation } \\
(\mathrm{m})\end{array}$ & $\begin{array}{l}\text { Solum/ } \\
\text { thickness }(\mathrm{m})\end{array}$ & & $\begin{array}{l}\text { Classification } \\
\text { WRB system }^{\mathrm{b}}\end{array}$ \\
\hline PK-1 & 1 & W & 443 & 200 & Ferralsol & Soil toxonomy \\
PK-2 & 5 & N40W & 431 & 180 & Acrisol & Typic Hapludox \\
PK-3 & 1 & S50W & 410 & 160 & Acrisol & Typic Paleudult \\
PK-4 & 3 & N50E & 386 & 100 & Acrisol & Typic Hapludult \\
PK-5 & 1 & S & 330 & 140 & Acrisol & Typic Paleudult \\
PK-6 & 5 & E & 320 & 114 & Cambisol & Typic Dystrudept \\
\hline
\end{tabular}

\footnotetext{
${ }^{a}$ All the pedons were sampled near the hinge line zone of the anticlinal tableland.

b ISSS Working Group WRB (1998).

c Soil Survey Staff (2003).
} 
the Quaternary Taichung basin to the east (Fig. 1B). This tableland comprises Quaternary terrestrial sediments asymmetrically folded as an active anticline (above a décollement in Miocene rocks at a depth of $>4 \mathrm{~km}$ ) by frontal thrusting of the Changhua Fault system in caused by crustal shortening (Hsiao, 1968; Chen, 1978; Lee et al., 1996; Deffontaines et al., 1997; Delcaillau et al., 1998; Mouthereau et al., 1999). The western limb of the tableland is narrower and dips more steeply than the other. The deformed strata of the Tokoshan formation indicate that the tableland uplift began at approximately 500-400 ka (Delcaillau et al., 1998). Although the subsurface geometry of the Changhua Fault has been described based on seismic and borehole data (Hsiao, 1968; Chen, 1978, Wang et al., 2003), the fault outcrop has not been found. A geologic basement high, the Peikang High, is located west of the anticline and Changhua Fault (Biq, 1992; Lu et al., 1998). The obstacle effect resulted in the deformation of the tableland in a sigmoidal shape trending running NNW in the north to

Table 2

The morphological characteristics and the quantification of the six pedons

\begin{tabular}{|c|c|c|c|c|c|c|c|c|c|c|c|c|c|}
\hline \multirow[t]{2}{*}{ Pedon } & \multirow[t]{2}{*}{ Horizon } & \multirow{2}{*}{$\begin{array}{l}\text { Depth } \\
(\mathrm{cm})\end{array}$} & \multicolumn{2}{|c|}{ Munsell color } & \multirow[t]{2}{*}{ Texture $^{a}$} & \multirow[t]{2}{*}{ Structure $^{b}$} & \multicolumn{3}{|c|}{ Consistence $^{\mathrm{c}}$} & \multirow{2}{*}{$\begin{array}{l}\text { Clay } \\
\text { coatings }\end{array}$} & \multirow[t]{2}{*}{$\mathrm{RI}^{\mathrm{e}}$} & \multirow[t]{2}{*}{$\mathrm{HI}^{\mathrm{f}}$} & \multirow[t]{2}{*}{$\mathrm{WPDI}^{8}$} \\
\hline & & & Moist & Dry & & & Dry & Moist & Wet & & & & \\
\hline \multirow[t]{6}{*}{$\overline{\mathrm{PK}-1}$} & A1 & $0-30$ & 5YR 5/8 & 5 YR $6 / 8$ & $\mathrm{SiC}$ & $3 \mathrm{fm}$ and csbk & $\mathrm{h}$ & fir & vsp & $-{ }^{\mathrm{h}}$ & 8 & 0.68 & 0.73 \\
\hline & Bo1 & $30-70$ & $2.5 \mathrm{YR} 4 / 8$ & $2.5 \mathrm{YR} 6 / 8$ & $\mathrm{SiC}$ & $3 \mathrm{~m}$ and cvcsbk & $\mathrm{h}$ & fir & vsp & - & 15 & 0.70 & \\
\hline & Bo2 & $70-110$ & $2.5 \mathrm{YR} 4 / 8$ & 2.5 YR $6 / 8$ & $\mathrm{SiC}$ & $3 \mathrm{mc}$ and vcsbk & $\mathrm{vh}$ & fir & vsp & fdpf & 15 & 0.75 & \\
\hline & Bo3 & $110-140$ & $2.5 \mathrm{YR} 4 / 6$ & $2.5 \mathrm{YR} 6 / 8$ & $\mathrm{SiC}$ & $\mathrm{s}$ and vesbk & vh & fir & vsp & fdpf & 11 & 0.73 & \\
\hline & Bo4 & $140-160$ & $2.5 \mathrm{YR} 4 / 6$ & $2.5 \mathrm{YR} 6 / 8$ & $\mathrm{SiC}$ & $\mathrm{mc}$ and vesbk & vh & fir & vsp & fdpf & 11 & 0.73 & \\
\hline & Bo5 & $160-200$ & $2.5 \mathrm{YR} 4 / 6$ & 2.5 YR $6 / 8$ & $\mathrm{SiC}$ & $3 \mathrm{mc}$ and vcsbk & $\mathrm{vh}$ & vfir & vsp & fdpf & 11 & 0.76 & \\
\hline \multirow[t]{6}{*}{ PK-2 } & A & $0-20$ & $7.5 \mathrm{YR} 4 / 6$ & 7.5YR $6 / 6$ & $\mathrm{SiC}$ & $3 \mathrm{f}$ and $\mathrm{msbk}$ & $\mathrm{h}$ & fir & $\mathrm{sp}$ & cdpo & 4 & 0.64 & 0.68 \\
\hline & Bt1 & $20-51$ & $7.5 \mathrm{YR} \mathrm{5/8}$ & 7.5YR 5/8 & $\mathrm{SiCL}$ & $3 \mathrm{~m}$ and csbk & $\mathrm{vh}$ & fir & $\mathrm{sp}$ & cdpo & 4 & 0.66 & \\
\hline & $\mathrm{Bt} 2$ & $51-85$ & $5 Y R$ 5/6 & $5 \mathrm{YR} 7 / 6$ & $\mathrm{SiC}$ & $3 \mathrm{f}$ and mabk & $\mathrm{vh}$ & fir & vsp & cdpo & 6 & 0.70 & \\
\hline & $\mathrm{Bt} 3$ & $85-120$ & $5 \mathrm{YR} 5 / 6$ & $5 \mathrm{YR} 6 / 6$ & $\mathrm{SiC}$ & $3 \mathrm{~m}$ and cabk & vh & fir & vsp & cdpo & 6 & 0.70 & \\
\hline & $\mathrm{Bt} 4$ & $120-145$ & $5 \mathrm{YR} 5 / 6$ & $5 \mathrm{YR} 6 / 6$ & $\mathrm{SiC}$ & $3 \mathrm{~m}$ and cabk & $\mathrm{vh}$ & fir & vsp & cdpo & 6 & 0.70 & \\
\hline & $\mathrm{Bt} 5$ & $>145$ & $5 Y R 5 / 6$ & 5 YR 7/6 & $\mathrm{SiC}$ & $3 \mathrm{~m}$ and csbk & $\mathrm{vh}$ & fir & vsp & cdpo & 6 & 0.70 & \\
\hline \multirow[t]{5}{*}{ PK-3 } & $\mathrm{A}$ & $0-25$ & $7.5 \mathrm{YR} 5 / 6$ & 7.5 YR $6 / 6$ & $\mathrm{SiCL}$ & $3 \mathrm{~m}$ and fsbk & $\mathrm{sh}$ & fir & wsp & - & 3 & 0.57 & 0.64 \\
\hline & $\mathrm{AB}$ & $25-55$ & $7.5 \mathrm{YR} 5 / 8$ & 7.5YR $6 / 8$ & $\mathrm{SiCL}$ & $3 \mathrm{~m}$ and csbk & sh & fir & $\mathrm{sp}$ & - & 4 & 0.61 & \\
\hline & $\mathrm{Bt} 1$ & $55-80$ & $7.5 \mathrm{YR} 5 / 8$ & 7.5 YR $6 / 8$ & CL & $3 \mathrm{~m}$ and cabk & $\mathrm{h}$ & fir & vsp & cdpo & 4 & 0.68 & \\
\hline & $\mathrm{Bt} 2$ & $80-115$ & $5 Y R 4 / 6$ & 5YR 5/8 & $\mathrm{C}$ & $3 \mathrm{~m}$ and cabk & $\mathrm{vh}$ & fir & vsp & cdpo & 7.5 & 0.69 & \\
\hline & $\mathrm{Bt} 3$ & $115-160$ & 5 YR $5 / 8$ & 5 YR $6 / 8$ & $\mathrm{CL}$ & $3 \mathrm{c}$ and $\mathrm{mfabk}$ & vh & vfir & $\mathrm{sp}$ & cdpo & 8 & 0.67 & \\
\hline \multirow[t]{4}{*}{ PK-4 } & A & $0-18$ & $7.5 \mathrm{YR} 7 / 8$ & $7.5 Y R$ 7/4 & $\mathrm{SiC}$ & $3 \mathrm{~m}$ and fsbk & sh & $\mathrm{fr}$ & wsp & - & 3 & 0.50 & 0.58 \\
\hline & $\mathrm{Bt1}$ & $18-40$ & $7.5 \mathrm{YR} 6 / 8$ & $7.5 Y R 7 / 6$ & $\mathrm{SiC}$ & $3 \mathrm{~m}$ and fsbk & $\mathrm{h}$ & $\mathrm{fr}$ & wsp & - & 3 & 0.57 & \\
\hline & $\mathrm{Bt} 2$ & $40-70$ & 7.5 YR $5 / 8$ & 7.5 YR $6 / 6$ & $\mathrm{C}$ & $3 \mathrm{~m}$ and csbk & $\mathrm{h}$ & $\mathrm{fr}$ & $\mathrm{sp}$ & - & 4 & 0.61 & \\
\hline & $\mathrm{Bt} 3$ & $70-100$ & $7.5 \mathrm{YR} 5 / 8$ & $7.5 Y R 7 / 6$ & $\mathrm{C}$ & $3 \mathrm{~m}$ and csbk & $\mathrm{h}$ & $\mathrm{fr}$ & $\mathrm{sp}$ & - & 4 & 0.61 & \\
\hline \multirow[t]{5}{*}{ PK-5 } & A & $0-20$ & $7.5 \mathrm{YR} 4 / 6$ & $7.5 \mathrm{YR} 6 / 6$ & $\mathrm{CL}$ & $2 \mathrm{~m}$ and fsbk & $\mathrm{sh}$ & $\mathrm{fr}$ & wsp & - & 3.75 & 0.44 & 0.53 \\
\hline & $\mathrm{AB}$ & $20-45$ & $7.5 \mathrm{YR} 4 / 6$ & 7.5 YR $6 / 6$ & $\mathrm{SiCL}$ & $2 \mathrm{~m}$ and fabk & $\mathrm{sh}$ & $\mathrm{fr}$ & wsp & - & 3.75 & 0.46 & \\
\hline & Bt1 & $45-70$ & 5YR 5/6 & $5 Y R 6 / 6$ & $\mathrm{SiCL}$ & $2 \mathrm{~m}$ and cabk & $\mathrm{h}$ & $\mathrm{fr}$ & $\mathrm{sp}$ & - & 6 & 0.53 & \\
\hline & $\mathrm{Bt} 2$ & $70-95$ & $5 Y R$ 4/6 & $5 Y R 6 / 8$ & $\mathrm{CL}$ & $2 \mathrm{~m}$ and fabk & $\mathrm{h}$ & fr & $\mathrm{sp}$ & - & 7.5 & 0.56 & \\
\hline & $\mathrm{Bt} 3$ & $95-140$ & $5 Y R 4 / 6$ & 5 YR $6 / 8$ & $\mathrm{C}$ & $2 \mathrm{~m}$ and fabk & $\mathrm{h}$ & $\mathrm{fr}$ & $\mathrm{sp}$ & - & 7.5 & 0.60 & \\
\hline \multirow[t]{5}{*}{ PK-6 } & A & $0-35$ & 10YR 6/6 & 10YR 7/4 & $\mathrm{CL}$ & $2 \mathrm{fmg}$ and fmsbk & $\mathrm{sh}$ & $\mathrm{fr}$ & wsp & - & 0 & 0.40 & 0.43 \\
\hline & Bw1 & $35-60$ & 10 YR $5 / 8$ & $10 Y R 6 / 4$ & $\mathrm{CL}$ & $2 \mathrm{fm}$ and csbk & $\mathrm{sh}$ & $\mathrm{fr}$ & wsp & - & 0 & 0.42 & \\
\hline & Bw2 & $60-90$ & 10YR 5/8 & 10YR 6/4 & $\mathrm{CL}$ & $2 \mathrm{fm}$ and csbk & $\mathrm{sh}$ & $\mathrm{fr}$ & wsp & - & 0 & 0.42 & \\
\hline & Bw3 & $90-114$ & $7.5 \mathrm{YR} 5 / 8$ & 7.5 YR $6 / 6$ & $\mathrm{CL}$ & $2 \mathrm{fm}$ and csbk & $\mathrm{sh}$ & $\mathrm{fr}$ & wsp & - & 4 & 0.46 & \\
\hline & Bw4 & $>114$ & 7.5 YR $5 / 8$ & 7.5 YR $6 / 6$ & $\mathrm{CL}$ & $2 \mathrm{fm}$ and sbk & $\mathrm{sh}$ & $\mathrm{fr}$ & wsp & - & 4 & 0.46 & \\
\hline Parent material & & & $5 \mathrm{GY} 3 / 1$ & $5 \mathrm{GY} 4 / 1$ & $\mathrm{~S}$ & o & lo & lo & sopo & - & & & \\
\hline
\end{tabular}

${ }^{\text {a }}$ Using the US system; $\mathrm{SL}=$ sandy loam, $\mathrm{C}=$ clay, $\mathrm{CL}=$ clay loam, $\mathrm{SiC}=$ silty clay, $\mathrm{SiCL}=$ silty clay loam.

b $\mathrm{sg}=$ single grain. $3=$ strong, $2=$ moderate, $1=$ weak, $\mathrm{f}=$ fine, $\mathrm{vf}=$ very fine, $\mathrm{m}=$ medium, $\mathrm{c}=$ coarse, gr=granular, abk=angular blocky, sbk $=$ subangular blocky, $\mathrm{vc}=$ very coarse.

${ }^{\mathrm{c}} \mathrm{h}=$ hard, lo=loose, fir $=$ firm, fr $=$ friable, $\mathrm{v}=$ very, $\mathrm{w}=$ weak, $\mathrm{o}=$ none, $\mathrm{s}=$ sticky, $\mathrm{p}=$ plastic.

${ }^{\mathrm{d}} \mathrm{f}=\mathrm{few} ; \mathrm{c}=$ common; $\mathrm{d}=$ distinct; $\mathrm{pf}=$ ped face; $\mathrm{po}=$ line tubular or interstitial pores.

${ }^{\mathrm{e}}$ Redness index $=[(10-$ hue $) \times$ chroma $] /$ value $($ Torrent et al., 1980, 1983).

${ }^{\mathrm{f}}$ Horizon index, PDI $=$ the sum of HI multiplied by horizon thickness (Appendix 2 in Birkeland, 1999).

$\mathrm{g}$ Weighted mean profile development index, WPDI=PDI divided by the pedon thickness (Appendix 2 in Birkeland, 1999).

${ }^{\mathrm{h}}$ No feature. 
NS in the south (Lee et al., 1996; Mouthereau et al., 1999; Sung and Chen, 2004).

\subsection{Landscape}

The southern part of the Pakua tableland comprises a series of wide unpaired terraces. These terraces can be divided into 6 levels, from PK-1 (highest, $440 \mathrm{~m}$ above the sea level) to PK-6 (lowest, $300 \mathrm{~m}$ above the sea level) (Fig. 2). All terraces are covered with red soils and gravels, and are designated as 'lateritic terraces' (Lin, 1957). The soil and gravel deposits are well preserved along the hinge zone line and on the eastern backlimb of the anticlinal Pakua tableland. Based on current evidence, terraces with red topsoil in Taiwan date to before the age of $30 \mathrm{ka}$ (Liew, 1988; Chen and Liu, 1991; Ota et al., 2002). Strata under terrace gravels are composed of coarse conglomerate deposits of the upper Pleistocene Tokoshan formation (0.8-0.5 Ma) (Chang and Chi, 1983; Teng, 1987). These well sorted conglomerates are consolidating cemented, and sometimes contain fractures resulting from mountain building (tectonic compression) during the Plio-Pleistocene (Ho, 1988). However, the boundary between terrace gravels and conglomerate deposits in the field is often ambiguous (Tsai and Sung, 2000).

The conglomerate and gravel strata were deposited as large coalescing alluvial fans on the coastal plain. A palynology correlation indicates that the alluvial fans were likely deposited during 70-350 ka (Liew, 1988). Terrace PK-1 is one of a remnant surface of the alluvial fans deposited by the Choshui River and its tributaries. Terraces PK-2 to PK-6, descending northeastward in altitude, are the result of a long-term northward migration of the Choshui River (Shih and Yang, 1985). The dark sediments of the Choshui River are mainly eroded slate, phyllite and quartzite from the Tertiary metamorphic terrain. The lower reach of the Choshui River migrates around the southern end of the Pakua tableland probably caused by further uplifting of the tableland (Shih and Yang, 1985).

\subsection{Climate and vegetation}

The study area climate is characterized by high temperature and humidity, substantial rainfall, and summer tropical cyclones. Annual average temperature is $23{ }^{\circ} \mathrm{C}$. The warmest average temperature is approximately $30{ }^{\circ} \mathrm{C}$ in July, whereas the coldest average temperature is roughly $16{ }^{\circ} \mathrm{C}$ in January. Seasonal oscillations between dry in winter and wet in summer comprise a wet-dry tropical climate ( $\mathrm{Cwa}$ ) based on
Köppen's climate classifications. Subtropical broadleaved evergreen forests are predominant in this area. However, tea farming in this area has dramatically increased over the past three decades.

A paleoclimate is a warm-cold-warm cycle during glacial-interglacial periods of the Pleistocene. The cold and dry conditions that existed during the mid-Pleistocene are considered younger than the Jaramillo event that occurred at about 0.7-0.9Ma (Tseng et al., 1992; Liew and Huang, 1994). The warm-temperate to subtropical climatic conditions continued and were separated by three very humid intervals during the early and mid Holocene (Chen and Liew, 1990; Liew and Hsieh, 2000). Palynological evidence indicates that a warmer annual temperature of $1 \pm 2{ }^{\circ} \mathrm{C}$ with a relatively higher amount of precipitation existed during the warm interval compared

Table 3

Particle size distribution of the six pedons

\begin{tabular}{|c|c|c|c|c|c|c|c|c|c|}
\hline \multirow[t]{2}{*}{ Pedon } & \multirow[t]{2}{*}{ Horizon } & \multicolumn{3}{|c|}{ Total $(100 \%)$} & \multicolumn{5}{|c|}{ Sand-size class } \\
\hline & & Sand & Silt & Clay & $\mathrm{VC} \%$ & $\mathrm{C} \%$ & M\% & $\mathrm{F} \%$ & VF\% \\
\hline \multirow[t]{6}{*}{ PK-1 } & A1 & 8 & 52 & 40 & 0 & 0.2 & 0.2 & 1.8 & 5.7 \\
\hline & Bo1 & 7 & 50 & 43 & 0 & 0.1 & 0.2 & 1.5 & 4.9 \\
\hline & Bo2 & 6 & 46 & 48 & 0 & 0.1 & 0.2 & 1.2 & 4.1 \\
\hline & Bo3 & 5 & 45 & 50 & 0 & 0 & 0.2 & 1.3 & 4.0 \\
\hline & Bo4 & 5 & 47 & 48 & 0 & 0 & 0.2 & 1.2 & 4.1 \\
\hline & Bo5 & 5 & 46 & 49 & 0 & 0.1 & 0.1 & 1.2 & 4.0 \\
\hline \multirow[t]{6}{*}{ PK-2 } & $\mathrm{A}$ & 11 & 49 & 40 & 0 & 0.2 & 0.5 & 2.4 & 6.3 \\
\hline & Bt1 & 9 & 47 & 44 & 0 & 0.4 & 0.5 & 3.2 & 5.4 \\
\hline & $\mathrm{Bt} 2$ & 9 & 46 & 45 & 0.1 & 0.3 & 0.5 & 1.9 & 4.9 \\
\hline & $\mathrm{Bt} 3$ & 8 & 45 & 47 & 1.2 & 0.6 & 0.6 & 3.6 & 5.2 \\
\hline & $\mathrm{Bt} 4$ & 10 & 44 & 46 & 0 & 0.3 & 0.5 & 3.5 & 5.8 \\
\hline & $\mathrm{Bt} 5$ & 10 & 45 & 45 & 0 & 0.5 & 0.5 & 3.6 & 6.1 \\
\hline \multirow[t]{5}{*}{ PK-3 } & A & 16 & 46 & 38 & 0.2 & 0.8 & 4.3 & 5.8 & 5.3 \\
\hline & $\mathrm{AB}$ & 19 & 42 & 39 & 0.4 & 2.3 & 2.1 & 4.4 & 10.2 \\
\hline & Bt1 & 21 & 48 & 31 & 0.2 & 4.1 & 2.8 & 5.3 & 8.4 \\
\hline & Bt2 & 20 & 39 & 41 & 0.3 & 3.0 & 5.8 & 5.3 & 5.2 \\
\hline & $\mathrm{Bt} 3$ & 22 & 40 & 38 & 0.3 & 3.4 & 2.7 & 5.8 & 9.7 \\
\hline \multirow[t]{4}{*}{ PK-4 } & A & 14 & 46 & 40 & 0.4 & 2.0 & 2.2 & 4.2 & 5.2 \\
\hline & Bt1 & 15 & 41 & 48 & 0.8 & 3.1 & 2.6 & 4.0 & 4.1 \\
\hline & Bt2 & 16 & 37 & 49 & 1.1 & 3.0 & 3.0 & 4.9 & 4.4 \\
\hline & $\mathrm{Bt} 3$ & 17 & 37 & 48 & 1.9 & 3.2 & 2.7 & 4.9 & 4.6 \\
\hline \multirow[t]{5}{*}{ PK-5 } & A & 22 & 50 & 28 & 0.1 & 1.9 & 3.1 & 5.7 & 11.1 \\
\hline & $\mathrm{AB}$ & 19 & 52 & 29 & 0.2 & 3.0 & 4.2 & 5.3 & 6.3 \\
\hline & $\mathrm{Bt} 1$ & 19 & 41 & 40 & 0 & 2.4 & 3.4 & 6.4 & 7.1 \\
\hline & $\mathrm{Bt} 2$ & 21 & 41 & 38 & 0.4 & 3.5 & 3.6 & 6.3 & 7.5 \\
\hline & $\mathrm{Bt} 3$ & 21 & 36 & 43 & 0.5 & 2.7 & 3.4 & 6.1 & 8.6 \\
\hline \multirow[t]{5}{*}{ PK-6 } & A & 27 & 44 & 29 & 1.4 & 4.7 & 4.1 & 8.0 & 9.3 \\
\hline & Bw1 & 27 & 40 & 33 & 0.7 & 3.5 & 4.0 & 9.0 & 9.6 \\
\hline & Bw2 & 27 & 34 & 39 & 1.2 & 4.6 & 4.4 & 8.7 & 8.3 \\
\hline & Bw3 & 25 & 37 & 38 & 1.3 & 4.3 & 4.0 & 8.7 & 6.7 \\
\hline & Bw4 & 25 & 39 & 36 & 1.0 & 3.5 & 3.9 & 8.9 & 7.6 \\
\hline
\end{tabular}

$\mathrm{VC}=$ very coarse $(2.00-1.00 \mathrm{~mm}) ; \mathrm{C}=$ coarse $(1.00-0.50 \mathrm{~mm})$; $\mathrm{M}=$ medium $(0.50-0.25 \mathrm{~mm}) ; \mathrm{F}=$ fine $(0.25-0.10 \mathrm{~mm}) ; \mathrm{VF}=$ very fine $(0.10-0.05 \mathrm{~mm})$. 
with the cool-dry interval in mid-Pleistocene (Liew and Hsieh, 2000).

\section{Material and methods}

\subsection{Pedons}

Terrace surface deposits are well preserved along the hinge and eastern backlimb of the anticline (Pakua tableland). According to field observations, the soils measure are $>4 \mathrm{~m}$ thick above the gravels in terrace PK-1, and about 1-2 $\mathrm{m}$ in terraces PK 2-6. Soil color ranges from strong brown to yellowish red in a trend that roughly agrees with the increasing terrace altitude; i.e. as altitude increases, the soil color reddens.

Six pedons, labeled as the terraces, were sampled following guidelines in the Soil Survey Manual (Soil Survey Staff, 1993). Each pedon is situated on the planar surface near the anticline hinge where the soil (and/or the surface) is well preserved without gully erosion (Fig. 2). Saldaña et al. (1998) proposed that variability of soil properties decreases as soil deposits age. The soils in the Pakua tableland may be sufficiently old to have homogenous soil properties. Furthermore, the uniform color and thickness of soil in each terrace and the similar climate, vegetation, groundwater, and drainage conditions suggest that the spatial variability of soil properties is insignificant in the study area. Therefore, each pedon is considered to be representative of its terrace. Table 1 presents the type and location of the pedons.

\subsection{Morphological quantification}

PDI measures the degree of pedogenic change that has occurred in the parent material with a single value (Bilzi and Ciolkosz, 1977; Harden, 1982). This study applied, with minor modification, guidelines developed by Harden (1982) and Harden and Taylor (1983) to calculate the PDI for each pedon using the following six properties: (i) rubification (color hue and chroma in moist and dry conditions); (ii) total texture (texture class and soil stickiness and plasticity); (iii) structure (type and degree of developed soil structure); (iv) moist consistence (class); (v) dry consistence (class); and, (vi) clay coatings (abundance, thickness, and location). However, the $\mathrm{pH}$ and soil color values (light or dark) used in Harden's (1982) original method were not used in the calculations. The $\mathrm{pH}$ was omitted from the calculation due to its susceptibility to disturbance by human activities, i.e., ploughing and fertilization in the study area. Soil color value (light to dark) has been considered a critical soil property, primarily in the early stages of pedogenesis, because organic matter content increases relatively rapidly and achieves a steady state

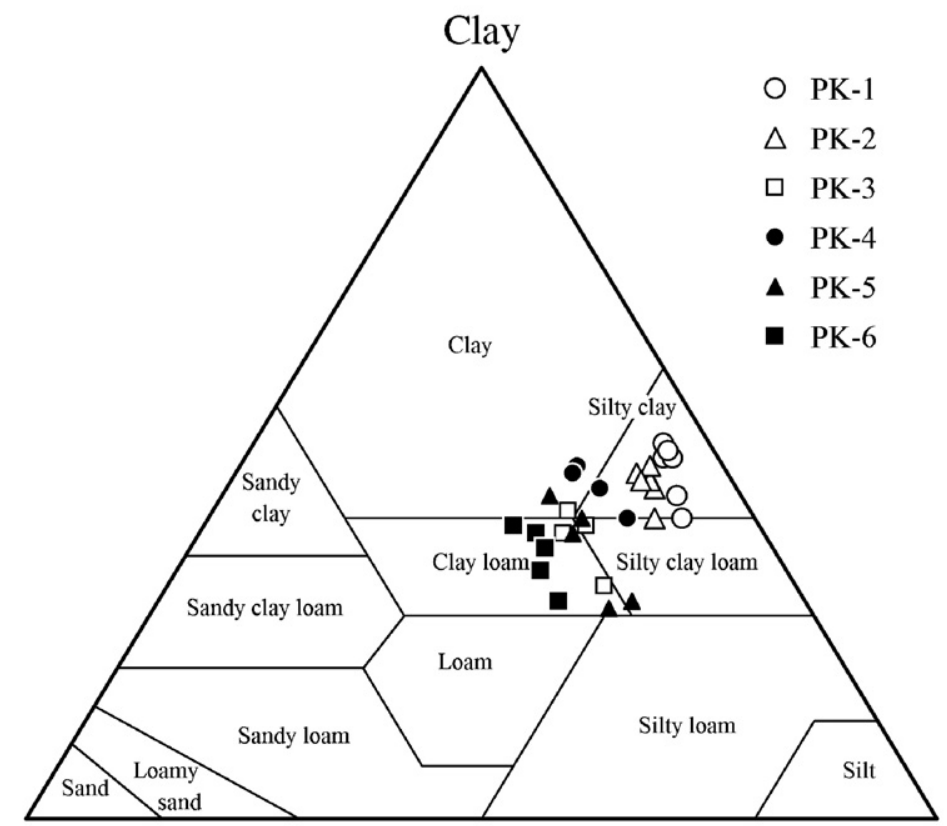

Sand

Silt

Fig. 3. Particle size distributions of the sampled pedons and the soil texture classes based on the USDA system. 

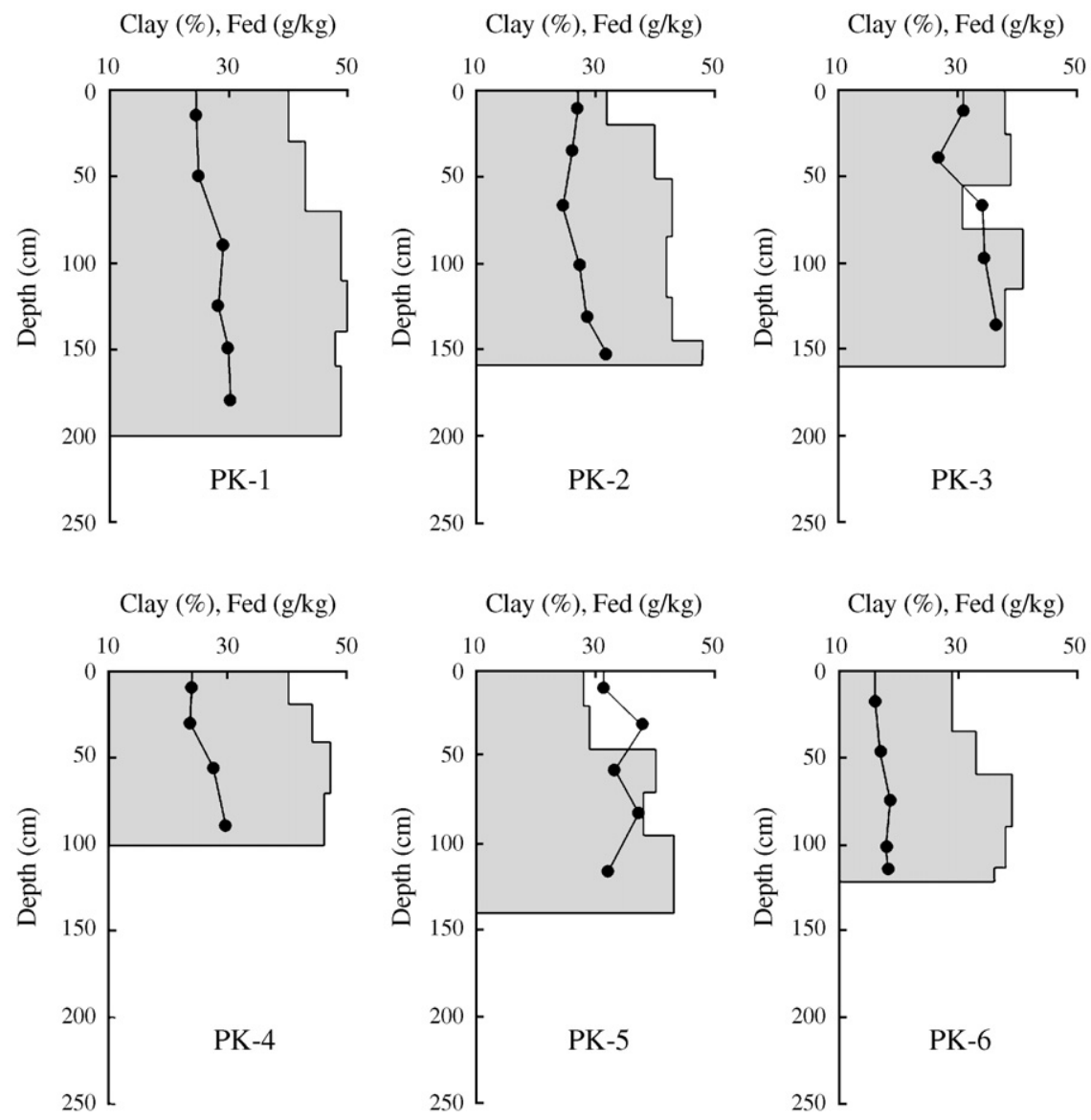

Fig. 4. The variations of vertical distribution in clay contents (shaded region) and $\mathrm{Fe}_{\mathrm{d}}$ (DCB-extractable Fe, expressed in solid circle) from the surface horizon to the lower horizon.

faster than any other soil property (Birkeland, 1999). However, organic matter decreased to a very low content over long-term development, resulting in insignificant variation in color values. The dark sediments of the Choshui River represent the parent constituents of study soils and is used in the calculation. The PDI value was further divided by the depth of described soil profile to produce weighted mean PDI (or WPDI) with values between 0 (no development) and 1 (maximum development) (Birkeland, 1999).

\subsection{Laboratory analyses}

Soil samples were collected from each profile horizon for physical and chemical analysis. Particle size distribution was determined using the pipette method (Gee and Bauder, 1986). The $\mathrm{pH}$ of air-dried samples $(<2 \mathrm{~mm})$ was determined for a mixture of soil/deionized water $(1: 1)$ using the glass-electrode method (McLean, 1982). Organic carbon (OC) content was measured using the Walkley-Black wet oxidation method (Nelson and Sommers, 1982). Cation exchange capacity and exchangeable bases were determined with the ammonium acetate technique (pH 7.0) (Rhoades, 1982). Total Fe $\left(\mathrm{Fe}_{\mathrm{t}}\right)$ and $\mathrm{Al}\left(\mathrm{Al}_{\mathrm{t}}\right)$ were determined using the Reisenauer (1982) method. Free $\mathrm{Fe}\left(\mathrm{Fe}_{\mathrm{d}}\right)$ and $\mathrm{Al}\left(\mathrm{Al}_{\mathrm{d}}\right)$ were extracted by the dithionite-citrate-bicarbonate (DCB) method (Mehra and Jackson, 1960). Amorphous Fe $\left(\mathrm{Fe}_{\mathrm{o}}\right)$ and $\mathrm{Al}\left(\mathrm{Al}_{\mathrm{o}}\right)$ were extracted by $0.2 \mathrm{M}$ ammonium oxalate (pH 3.0) (McKeague and Day, 1966). All metal concentrations were determined by atomic absorption spectrometry (Z-8100; Hitachi, Japan).

\section{Results}

\subsection{Soil morphology}

Throughout the Pakua tableland, pedon PK-1 on the oldest terrace level has the reddest hue, whereas pedon PK-6 on the youngest terrace level has the lightest red 
$\mathrm{HI}$

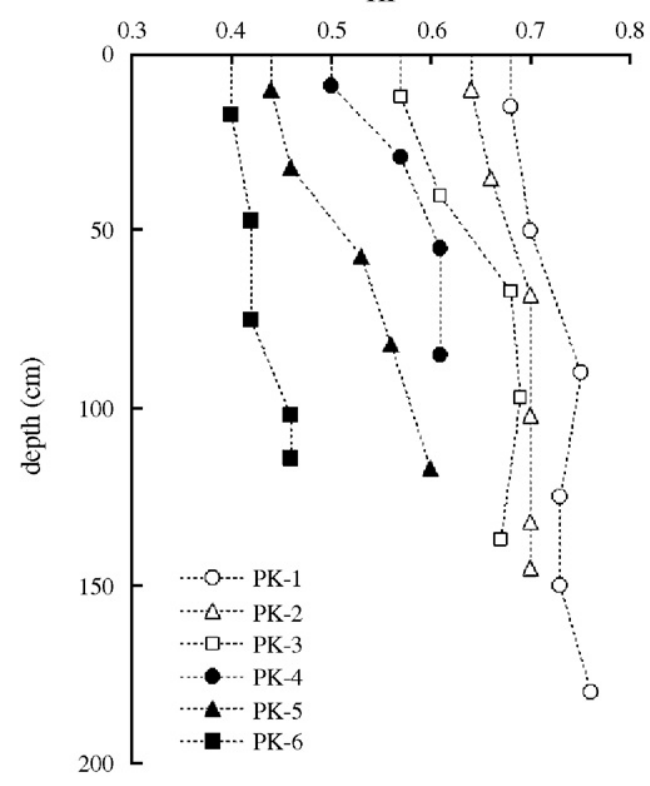

Fig. 5. The down-profile variation of HI (horizon index) in each pedon.

hues. For example, all oxic horizons (Bo) of pedon PK-1 have hues of $2.5 \mathrm{YR}$, which are markedly redder than those in the cambic horizons $(\mathrm{Bw})$ of pedon PK-6 (Table $2)$. Overall, the redness index decreases as terrace altitude decreases.

Strong chemical weathering conditions characterized by high air temperatures and heavy rainfall in the study area resulted in very low amounts of sand in the six pedons (Table 3; Fig. 3). Generally, the pedons have an increased sand fraction as terrace altitude decreases (PK-1 to PK-6). When the sand fraction is further divided into five size classes, the dominant classes are fine sand and very find sand (Table 3), suggesting that soil

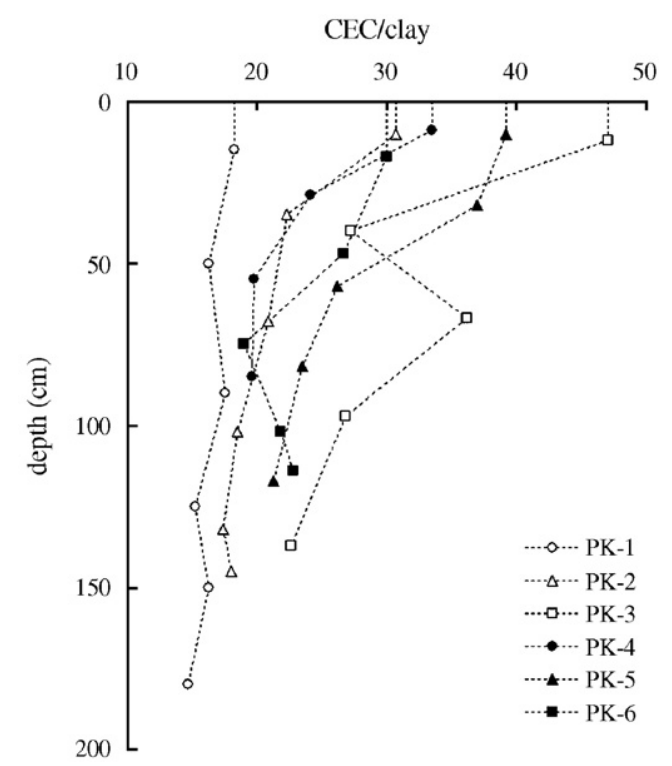

Fig. 7. The vertical variation in CEC/clay for the soil pedons.

parent materials were fine and subject to weathering, therefore, a high soil development rate probably exists. Among the soils, pedon PK-1 always has the lowest amount of each sand fraction, indicating that PK-1 was subjected to longer weathering of parent material than other soils. Variations in vertical distributions of clay and silt also suggest strong leaching within the pedons.

The soil texture is silty clay at high altitude terraces (PK-1 and PK-2), and clay loam at low altitude terraces (PK-6) (Table 2; Fig. 3). High clay content (>29\%) of the soils is associated with a very sticky and plastic consistency, resulting in coarse, strong angular blocky structures in the soils (especially for PK-1, PK-2 and PK-3 soils). Except for pedon PK-6, an argillic horizon (Bt) is

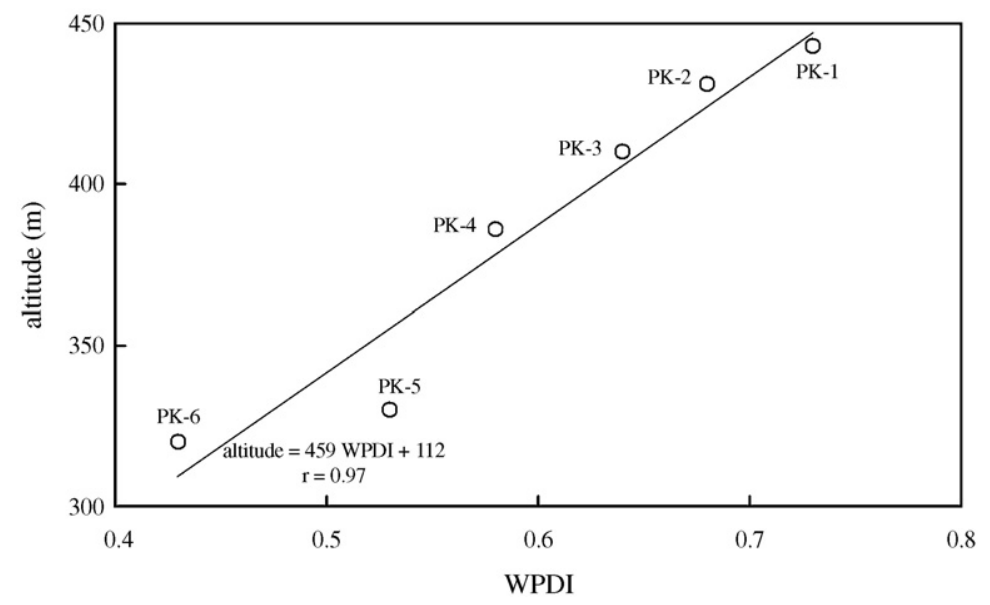

Fig. 6. The WPDI (weighted mean PDI) versus the elevation where the soils was sampled. 
Table 4

Selected physical and chemical properties of the six pedons

\begin{tabular}{|c|c|c|c|c|c|c|c|c|c|}
\hline Pedon & Horizon & $\mathrm{pH}$ & $\mathrm{OC}^{\mathrm{a}}(\mathrm{g} / \mathrm{kg})$ & $\mathrm{CEC}^{\mathrm{b}} \mathrm{cmol}^{(+)} / \mathrm{kg}$ & Oxalate $\mathrm{Fe}_{\mathrm{o}}(\mathrm{g} / \mathrm{kg})$ & DCB $F_{d}(g / k g)$ & Total $\mathrm{Fe}_{\mathrm{t}}(\mathrm{g} / \mathrm{kg})$ & $\mathrm{Fe}_{\mathrm{o}} / \mathrm{Fe}_{\mathrm{d}}$ & $\left(\mathrm{Fe}_{\mathrm{d}}-\mathrm{Fe}_{\mathrm{o}}\right) / \mathrm{Fe}_{\mathrm{t}}$ \\
\hline \multirow[t]{6}{*}{ PK-1 } & A1 & 4.2 & 4.4 & 7.3 & 1.8 & 24.6 & 35.8 & 0.07 & 0.64 \\
\hline & Bol & 4.5 & 4.8 & 7.0 & 1.7 & 25.0 & 32.3 & 0.07 & 0.72 \\
\hline & Bo2 & 4.4 & 3.2 & 8.4 & 2.1 & 29.1 & 37.8 & 0.07 & 0.72 \\
\hline & Bo3 & 4.4 & 3.6 & 7.6 & 2.2 & 28.3 & 35.7 & 0.08 & 0.73 \\
\hline & Bo4 & 4.4 & 2.4 & 7.8 & 2.0 & 30.0 & 34.7 & 0.06 & 0.81 \\
\hline & Bo5 & 4.5 & 2.0 & 7.2 & 1.6 & 30.4 & 33.5 & 0.05 & 0.86 \\
\hline \multirow[t]{6}{*}{ PK-2 } & A & 3.7 & 18.0 & 12.3 & 2.2 & 27.2 & 36.1 & 0.08 & 0.69 \\
\hline & Bt1 & 3.8 & 8.2 & 9.8 & 2.9 & 26.3 & 32.4 & 0.11 & 0.72 \\
\hline & $\mathrm{Bt} 2$ & 3.7 & 8.4 & 9.4 & 2.3 & 24.7 & 28.2 & 0.09 & 0.79 \\
\hline & $\mathrm{Bt} 3$ & 3.8 & 8.0 & 8.7 & 2.3 & 27.5 & 34.5 & 0.08 & 0.73 \\
\hline & $\mathrm{Bt} 4$ & 3.9 & 6.4 & 8.0 & 2.4 & 28.7 & 34.2 & 0.08 & 0.77 \\
\hline & Bt5 & 3.9 & 6.6 & 8.1 & 4.1 & 31.1 & 37.0 & 0.13 & 0.73 \\
\hline \multirow[t]{5}{*}{ PK-3 } & A & 3.8 & 17.2 & 11.0 & 4.0 & 31.1 & 36.5 & 0.13 & 0.74 \\
\hline & $\mathrm{AB}$ & 3.9 & 15.5 & 10.7 & 4.2 & 26.7 & 38.9 & 0.16 & 0.58 \\
\hline & Bt1 & 3.9 & 8.2 & 10.5 & 4.5 & 34.3 & 36.7 & 0.13 & 0.81 \\
\hline & Bt2 & 4.0 & 7.5 & 8.9 & 4.3 & 34.7 & 36.4 & 0.12 & 0.84 \\
\hline & $\mathrm{Bt} 3$ & 4.3 & 7.5 & 9.2 & 4.5 & 36.7 & 39.1 & 0.12 & 0.82 \\
\hline \multirow[t]{4}{*}{ PK-4 } & A & 4.1 & 17.5 & 13.4 & 2.9 & 23.8 & 26.4 & 0.12 & 0.79 \\
\hline & Bt1 & 4.2 & 15.0 & 10.6 & 2.6 & 23.5 & 31.0 & 0.11 & 0.67 \\
\hline & $\mathrm{Bt} 2$ & 4.2 & 7.7 & 9.3 & 2.8 & 27.4 & 33.4 & 0.10 & 0.73 \\
\hline & $\mathrm{Bt} 3$ & 4.3 & 7.7 & 9.0 & 2.8 & 29.5 & 35.3 & 0.09 & 0.76 \\
\hline \multirow[t]{5}{*}{ PK-5 } & A & 5.0 & 15.0 & 17.9 & 4.8 & 31.3 & 41.3 & 0.15 & 0.64 \\
\hline & $\mathrm{AB}$ & 3.9 & 12.4 & 10.6 & 5.3 & 37.9 & 42.9 & 0.14 & 0.76 \\
\hline & $\mathrm{Bt} 1$ & 3.9 & 7.8 & 11.2 & 6.6 & 33.2 & 45.4 & 0.20 & 0.59 \\
\hline & $\mathrm{Bt} 2$ & 3.8 & 5.5 & 11.0 & 7.1 & 37.2 & 43.7 & 0.19 & 0.69 \\
\hline & $\mathrm{Bt} 3$ & 3.9 & 4.8 & 8.6 & 6.3 & 31.9 & 42.1 & 0.20 & 0.61 \\
\hline \multirow[t]{5}{*}{ PK-6 } & A & 3.7 & 12.8 & 8.7 & 1.7 & 16.2 & 29.0 & 0.10 & 0.50 \\
\hline & Bw1 & 3.9 & 11.2 & 8.8 & 2.0 & 17.0 & 29.4 & 0.12 & 0.51 \\
\hline & Bw2 & 3.9 & 8.4 & 7.4 & 2.0 & 18.7 & 33.8 & 0.10 & 0.50 \\
\hline & Bw3 & 4.0 & 9.6 & 8.3 & 1.9 & 18.0 & 33.5 & 0.11 & 0.48 \\
\hline & Bw4 & 4.0 & 7.6 & 8.2 & 2.1 & 18.3 & 33.3 & 0.11 & 0.49 \\
\hline
\end{tabular}

a Organic carbon.

b Cation exchange capacity.

found in all the pedons, strongly exhibiting clay eluvialilluvial processes (Table 3; Fig. 4).

\subsection{Quantitative indices}

The soil morphology identified in this study was quantified according to the procedure described previously (Harden, 1982; Harden and Taylor, 1983). The horizon indices (HI) for each horizon increase with depth, and the transition to a sharp increase occurs below the surface at a depth about $40 \mathrm{~cm}$ (Fig. 5). Furthermore, degree of differentiation between each soil horizon becomes progressively greater on high terrace levels, developing higher HIs in subsurface B horizons. This HI pattern agrees with variations of vertical distribution in clay and $\mathrm{Fe}_{\mathrm{d}}$ content (Fig. 4).

As the described soil profiles typically have different thicknesses, the PDI values were further divided by the depth of soil profiles to produce WPDI with values between 0 (no development) and 1 (maximum development) (Birkeland, 1999) (Table 2). The WPDI values of study pedons are $0.34-0.56$ and increased as terrace altitude increased (Fig. 6).

\subsection{Chemical data}

All the soils contain low organic carbon concentrations $(<20 \mathrm{~g} / \mathrm{kg})$. The $\mathrm{pH}$ and cation exchange capacity (CEC) values are very low, indicating relatively low clay activity associated with strong leaching processes. When the CEC/clay data for the diagnostic subsurface horizons are examined, pedon PK-1 has the lowest value and pedon PK-6 has the highest value (Fig. 7). However, the $\mathrm{CEC} /$ clay values of most $\mathrm{B}$ horizons of pedon PK-1 are within the range commonly observed for low activity clays $(<16 \mathrm{cmol}(+) / \mathrm{kg})$ as defined in Soil Taxonomy (Soil Survey Staff, 2003). 
The color of soil parent material in the Pakua tableland is light olive brown (2.5Y 5/4). However, the six pedons have reddish colors, which is attributable to different degrees of chemical weathering associated with $\mathrm{Fe}$ released from silicate minerals. The DCB-extractable $\mathrm{Fe}$ of soils ranged up to slightly over $30 \mathrm{~g} / \mathrm{kg}$ (Table 4). Compared with DCB-extractable $\mathrm{Fe}$, the amount of oxalate-extractable $\mathrm{Fe}$ is extremely low, such that the ratio of oxalate to DCB-extractable $\mathrm{Fe}\left(\mathrm{Fe}_{\mathrm{o}} / \mathrm{Fe}_{\mathrm{d}}\right.$ value) is always $<0.2$, indicating a high degree of Fe crystallization (Blume and Schwertmann, 1969). The accumulation of DCB-extractable Fe in subsurface horizons indicates the migration of free $\mathrm{Fe}$ from the eluvial horizon to the lower horizons - although the high terrace level have more significant amounts of DCB-extractable Fe (Fig. 4).

\subsection{Soil classification}

Most soils in this study are classified as Ultisols according to Soil Taxonomy. Based on morphology, clay migration and CEC/clay data, pedon PK-1, whose subsurface horizons met the requirements of oxic horizon, is the oldest. Therefore, pedon PK-1 is classified as a fine, mixed, hyperthermic Typic Hapludox, indicating that it is an Oxisol that has $\geq 40 \%$ clay in its fine-earth fraction between the mineral soil surface and the depth of $18 \mathrm{~cm}$. Pedons PK-2, PK-3 and PK-5 are well-developed Ultisols classified as fine, mixed, hyperthermic Typic Paleudults. Pedon PK-4 is fine, mixed, hyperthermic Typic Hapludult. No accumulation of illuvial clay was found in the B horizons of pedon PK-6, indicating that pedon PK-6 is a Typic Dystrudept and is the youngest soil in the study area. A soil age sequence is also identified in the World Reference Base classification system. Thus, pedon PK-1 is a Haplic Ferralsol; pedons PK-2, PK-3, PK-4 and PK-5 are Haplic Acrisol; and pedon PK-6 is a Haplic Cambisol (ISSS Working Group WRB, 1998).

\section{Discussion}

\subsection{Pedogenesis and landscape}

All measured data indicate that the soils differ according to their development in a sequence from PK-1 to PK-6. The alumino-silicate clays were broken in accelerated desilication, as identified by Tsai et al. (2006), such that pedon PK-1 has the reddest hues (Table 2). Tsai et al. (2006) also indicated that type 2:1 clay minerals were destroyed and kaolinite and quartz formed and accumulated over time in sequence from PK-1 to PK-6. These characteristics suggest that the river terrace at high altitudes has highly developed soils and is older. The CEC/clay ratio of diagnostic subsurface horizons increases from the lowest level of terrace (PK-6) to middle levels (PK-2, PK-3, PK-4 and PK-5), because the clays were highly active at the young to mature stage of soil development. However, the amount of CEC/clay in diagnostic subsurface horizons declines from middle levels to the highest level (PK-1), suggesting that clay activities in the oldest soils are reduced by strongly chemical weathering and leaching along the chronosequence of this study.

The activity ratio $\left(\mathrm{Fe}_{\mathrm{o}} / \mathrm{Fe}_{\mathrm{d}}\right)$ (Blume and Schwertmann, $1969)$ and crystallinity ratio $\left(\mathrm{Fe}_{\mathrm{d}}-\mathrm{Fe}_{\mathrm{o}}\right) / \mathrm{Fe}_{\mathrm{t}}$ (Nagatsuka, 1972) of Fe have been used to assess soil development.

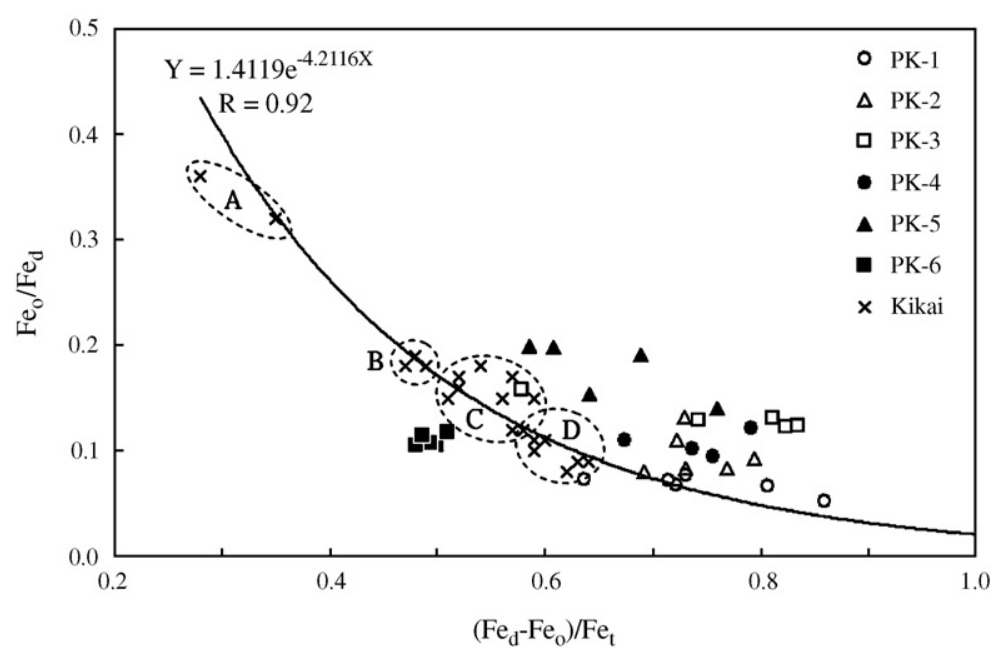

Fig. 8. The activity and crystallinity ratios of free iron for the soils of the Pakua tableland. The exponential curve fits the data of Kikai island (Maejima et al., 2002). The dashed circles indicate soils ages of A (3.5-3.9 ka), B (35-40 ka), C (50-80 ka), D (100-125 ka). 
For example, in northern Italy the $\left(\mathrm{Fe}_{\mathrm{d}}-\mathrm{Fe}_{\mathrm{o}}\right) / \mathrm{Fe}_{\mathrm{t}}$ ratios increase gradually with terrace age; however, the $\mathrm{Fe}_{\mathrm{d}} / \mathrm{Fe}_{\mathrm{t}}$ ratios decrease as pedon age increases (Arduino et al., 1984, 1986). Fig. 8 shows the values of $\left(\mathrm{Fe}_{\mathrm{o}} / \mathrm{Fe}_{\mathrm{d}}\right)$ and $\left(\mathrm{Fe}_{\mathrm{d}}-\mathrm{Fe}_{\mathrm{o}}\right) / \mathrm{Fe}_{\mathrm{t}}$ for all soils in the six pedons analyzed in this study. All data, except for pedon PK-6, are within Nagatsuka's (1972) red soil region $\mathrm{Fe}_{\mathrm{o}} / \mathrm{Fe}_{\mathrm{d}} \leq 0.4$, $\left(\mathrm{Fe}_{\mathrm{d}}-\right.$ $\left.\mathrm{Fe}_{\mathrm{o}}\right) / \mathrm{Fe}_{\mathrm{t}} \geq 0.5$. The highest terraces (i.e., PK-1 and PK-2) have low $\mathrm{Fe}_{\mathrm{o}} / \mathrm{Fe}_{\mathrm{d}}$ and high $\left(\mathrm{Fe}_{\mathrm{d}}-\mathrm{Fe}_{\mathrm{o}}\right) / \mathrm{Fe}_{\mathrm{t}}$ soil values. A trend exists in which the crystallinity ratio of free $\mathrm{Fe}$ gradually increased as terrace altitude increases, whereas the activity ratio decreases. This trend is similar to that obtained by Maejima et al. (2002), confirming that the highest river terrace in the Pakua tableland has more developed soils and is oldest.

Although the geomorphic surfaces of the Pakua tableland are generally regarded as river terraces created by fluvial processes (Shih and Yang, 1985), recent studies indicated that they resulted from normal faulting by local extension of a wrench tectonic environment (Mouthereau et al., 1999; Sung and Chen, 2004). In fact, an early investigation suggested that these major E-W scarps of the terraces were fault-related (Tomida, 1932). If the formation of the Pakua terraces is fault-related, the soils along the terrace will have a similar degree of soil development. In contrast, the terraces developed by
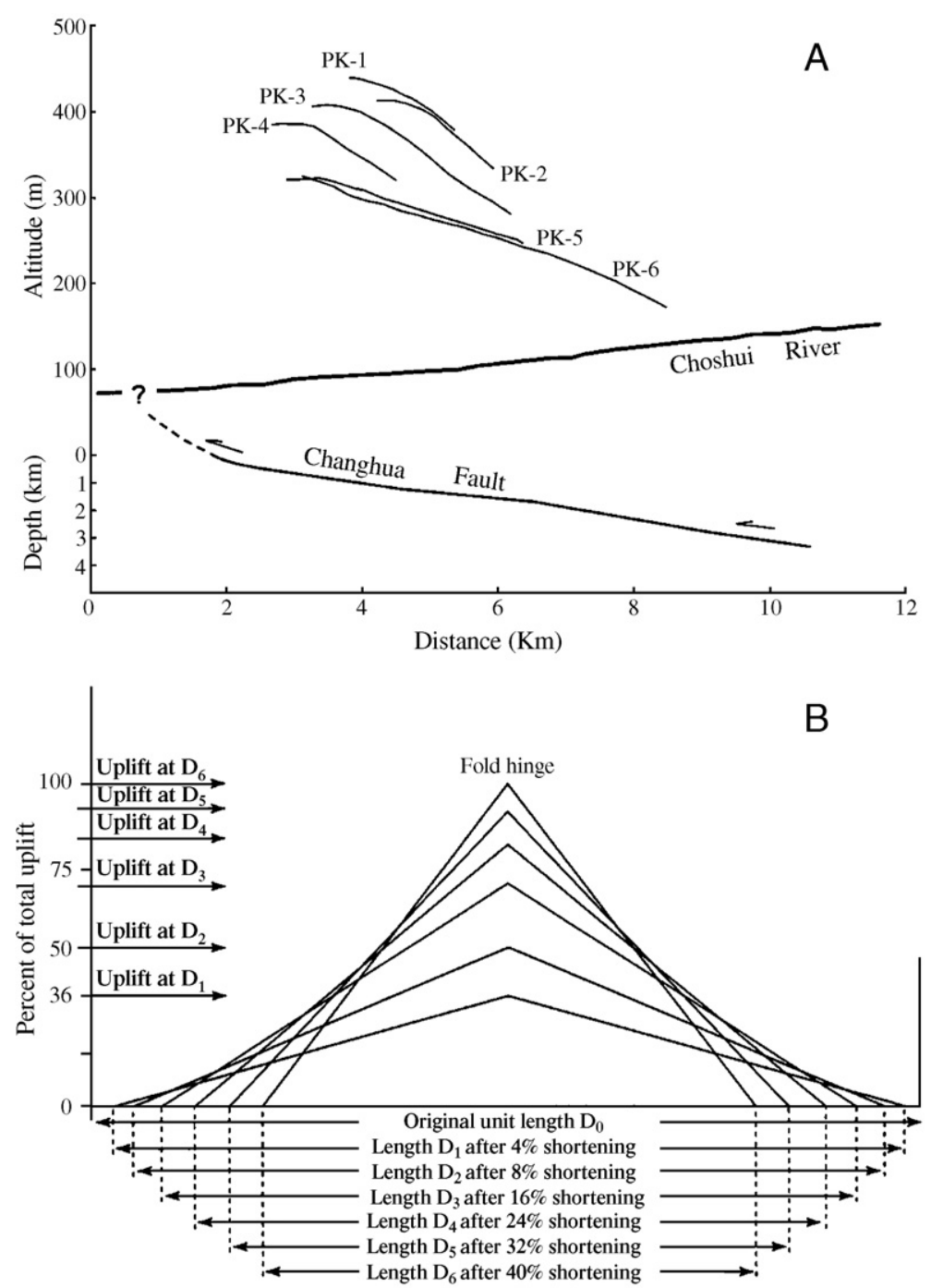

Fig. 9. (A) The geomorphic profiles of the terraces along the Choushui River. (B) The simple model proposed by Rockwell et al. (1984) depicting that, with folding above a décollement, a large amount of the uplift is produced early in the folding process. 
northward migration of the Choshui River will exhibit a soil chronosequence.

All study data demonstrate that the soils differ in duration of development, in a sequence moving from PK-1 to PK-6. The proposition that the surface deposits on the terraces began forming at different periods in the past and are still exposed is in agreement with the postincisive chronosequence described by Vreeken (1975). Therefore, the argument that the terraces were developed by successive river incision is supported.

\subsection{Age estimations for river terraces}

Terrace ages based on soil development can be estimated based on the positive relationship to Fe activity $\left(\mathrm{Fe}_{\mathrm{o}} / \mathrm{Fe}_{\mathrm{d}}\right)$ and the negative relationship to Fe crystallinity $\left(\mathrm{Fe}_{\mathrm{d}}-\mathrm{Fe}_{\mathrm{o}}\right) / \mathrm{Fe}_{\mathrm{t}}$ (Arduino et al., 1984; MacFadden and Hendricks, 1985; Arduino et al., 1986). Maejima et al. (2002) estimated the age of Lateritic red soils on Minamidaito Island based on Fe activity and crystallinity ratios of dated soils (from ca. 35 to $125 \mathrm{ka}$ ) from Kikai Island. The red soils of Kikai Island were developed from a coral reef. Chesworth (1973) argued that the affects by parent material are nullified with time. Soils in the Pakua tableland are probably $>30 \mathrm{ka}$ in age (Liew, 1988; Chen and Liu, 1991; Ota et al., 2002); the comparable oceanic subtropical climate shared by Kikai Island and the Pakua tableland may subject the soils to similar influences.

The Papua tableland soils have a pattern similar to those on Kikai Island (Fig. 8). The high $\left(\mathrm{Fe}_{\mathrm{d}}-\mathrm{Fe}_{\mathrm{o}}\right) / \mathrm{Fe}_{\mathrm{t}}$ ratios of PK-1, PK-2, PK-3 and PK-4 indicate that they may well be aged $>125 \mathrm{ka}$. The power equation of $\left(\mathrm{Fe}_{\mathrm{d}}{ }^{-}\right.$ $\left.\mathrm{Fe}_{\mathrm{o}}\right) / \mathrm{Fe}_{\mathrm{t}}=0.0687\left(\mathrm{Age}^{0.1857}\right.$ ) in Maejima et al. (2002) yields ages of $40-400 \mathrm{ka}$ for the soils of the Pakua terraces. However, age for individual soil sample is difficult to determine based on the overlapping range of $\left(\mathrm{Fe}_{\mathrm{d}}-\mathrm{Fe}_{\mathrm{o}}\right) / \mathrm{Fe}_{\mathrm{t}}$ values.

Assuming that soil formation began shortly after the formation of each river terrace, the estimated soil ages are relatively coincident with those of the river terraces. The maximum age determined by $\left(\mathrm{Fe}_{\mathrm{d}}-\mathrm{Fe}_{\mathrm{o}}\right) / \mathrm{Fe}_{\mathrm{t}}$ values supports Delcaillau et al. (1998) who indicated that the tableland uplift began roughly at 50-400 ka. Based on palynology analyses, Liew (1988) proposed that the terrace sediments were likely deposited during 70$350 \mathrm{ka}$. According to ${ }^{14} \mathrm{C}$ dating for the lateritic terraces in the Chushan area, geologically regarded as the southern extension of the Pakua anticline across the Choshui River, the terrace equivalent to the PK-6 terrace based on altitude is aged ca. $31 \mathrm{ka}$ (Ota et al., 2002). As a result, these age estimates based on pedogenesis in this study are in agreement with the estimation in previous studies for lateritic terraces in Taiwan.

\subsection{Morphotectonic implications}

The deformed multiple terraces on the Pakua tableland are a useful tool for investigating the active tectonics in this area (Fig. 9A). The accumulated surface deformation is confirmed by the increasing river terrace slopes and altitude (Fig. 9A). The linearity of WPDI values versus terrace altitudes suggests that the Pakua tableland was uplifted at constant rate when the terraces were developing, if the soil development in terms of WPDI value increases at a relatively uniform rate (Fig. 6). Based on these age estimations for terrace soil, the overall uplift rate for the Pakua tableland is estimated at $1.1 \mathrm{~mm} /$ year over the past $400 \mathrm{ka}$. This long-term uplift rate is attributable to about $0.33 \mathrm{~mm} /$ year during the 400-40 ka period (terrace development) and about $8 \mathrm{~mm} /$ year during the period from $40 \mathrm{ka}$ to present (no terraces development), supporting the estimation obtained by Delcaillau et al. (1998). The rapid local uplift rate since $40 \mathrm{ka}$ probably exceeds the rate of river incision, preventing the development of river terraces located lower than PK-6.

The Pakua tableland has surface and subsurface geometries similar to those of the Ventura Avenue anticline in California. Lee et al. (1996) attributed the surface deformation of the Pakua tableland to the Changhua Fault slipping beneath the tableland. Study of the Ventura Avenue anticline demonstrates that rates of tectonic activity vary over time and space as a result of folding mechanics (Rockwell et al., 1984). The steady shortening of rootless fold buckles accounts for the reduction in uplift rate (Fig. 9B). The varying uplift rates in the Pakua tableland reflect increased shortening by the Changhua Fault. Fold reconstruction indicates a horizontal east-west shortening rate that increased from $2.4 \mathrm{~mm} /$ year (400-40 ka) to $31 \mathrm{~mm} /$ year (from $40 \mathrm{ka}$ to present). These rates are in agreement with GPS measurements that recorded a $2-33 \mathrm{~mm} /$ year of instantaneous shortening velocities along the Changhua Fault between 1992 and 1994 (Yu et al., 1997).

Field and subsurface evidence shows that the Changhua Fault is buried and located at a depth of $3 \mathrm{~km}$, with little displacement near the surface (Hsiao, 1968; Chen, 1978; Central Geologic Survey, 2001). Recent shallow reflection seismic profiles demonstrated that the western wing of the asymmetric Pakua tableland is characterized by continuous and gently dipping strata with a dipping angle as high as $30^{\circ}$ (Wang et al., 2003), indicating the anticline is not locked up and allows for further deformation. Due to the 
obstacle of the Peikang High to the west, the Pakua tableland will further uplift in response to the crustal shortening by the Changhua Fault and tectonic compression from the east. This surface deformation can relieve tectonic pressure and prevent transfer of the boundary fault to the west. The Changhua Fault remains the western-most thrust, and is a boundary fault running along the deformation front in the foreland belt of western Taiwan. The thrusting of this fault is likely to become increasingly active in the future, presenting a potentially serious threat to Taiwan.

\section{Conclusions}

The terraces soils in the southern Pakua tableland were subject to considerable leaching and weathering. All soils, except for that of pedon PK-1 (Oxisol) and PK-6 (Inceptisol), are Ultisols based on Soil Taxonomy classifications. The field morphology and the chemical data indicate that these soils differ in development duration. The degree of soil development increases as altitude decreases in a sequence from PK-1 to PK-6. These soils form a postincisive soil chronosequence that conforms with the evolution of the geomorphic surface developed by successive river incision resulting from the northward migration of the Choushui River in the study area.

The river terraces of the Pakua tableland are clearly uplifted, tilted and folded by the Changhua Fault slipping beneath the tableland. Based on the age estimation for the terraces, rates of uplift and tilt have probably increased since folding began, from approximately $0.33 \mathrm{~mm} /$ year (400-40 ka) to about $8 \mathrm{~mm} /$ year (from $40 \mathrm{ka}$ to the present). The current rate of local uplift likely exceeds the rate of river incision, preventing the development of river terraces located lower than PK- 6 . The variation in previous uplift rates reflects the increased shortening by frontal thrusting of the Changhua Fault running beneath the tableland.

\section{Acknowledgements}

The authors would like to thank the National Science Council of the Republic of China, Taiwan, for financially supporting this research under Contract No. NSC 912116-M-018-001 and NSC 92-2116-M-018-002.

\section{References}

Alexander, E.B., 1974. Extractable iron in relation to soil age on terraces along the Truckee River, Nevada. Soil Sci. Soc. Am. Proc. 38, 121-124.

Alonso, P.C., Sierra, E., Ortega, C., Dorronsoro, 1994. Soil development indices of soils developed on fluvial terraces (Peòaranda de Bracamonte, Sala manca, Spain). Catena 23, 295-308.
Angelier, J., 1986. Geodynamics of Eurasia-Philippine sea plate boundary: preface. Tectonophysics 125, IX-X.

Arduino, E., Barberis, E., Carraro, F., Forno, M.G., 1984. Estimating relative ages from iron-oxide/total-iron ratios of soils in the western Po Valley, Italy. Geoderma 33, 39-52.

Arduino, E., Barberis, E., Marsan, F.A., Zanini, E., Franchini, M., 1986. Iron oxides and clay minerals within profiles as indicators of soil age in Northern Italy. Geoderma 37, 45-55.

Bockheim, J.G., Kelsey, H.M., Marshall III, J.G., 1992. Soil development, relative dating, and correlation of late Quaternary marine terraces in southwestern Oregan. Quat. Res. 37, 60-74.

Bilzi, A.F., Ciolkosz, E.J., 1977. A field morphology rating scale for evaluating pedological development. Soil Sci. 124, 45-48.

Biq, C., 1992. Another coastal range on Taiwan. Ti-Chi 12, 1-14 (in Chinese).

Birkeland, P.W., 1984. Holocene soil chronofunctions, Southern Alps, New Zealand. Geoderma 34, 115-134.

Birkeland, P.W., 1999. Soils and Geomorphology, 3rd ed. Oxford Univ. Press, New York.

Blume, H.P., Schwertmann, U., 1969. Genetic evaluation of profile distribution of aluminum, iron, and manganese oxides. Soil Sci. Soc. Am. Proc. 33, 438-444.

Bull, W.B., 1990. Stream-terrace genesis: implications for soil development. Geomorphology 3, 351-367.

Central Geologic Survey, 2001. An introduction to the active fault in Taiwan with explanatory text of the active fault map of Taiwan, scale 1:500,000, 2nd ed. Central Geologic Survey, Taiwan, Republic of China.

Chang, L.P., Chi, W.R., 1983. Neogene nannoplankton biostratigraphy in Taiwan and the tectonic implications. Petrol. Geol. Taiwan 19, 93-147.

Chen, F.Y., Liew, P.M., 1990. Palynological study of the Sungshan formation, Taipei basin. Proc. Geol. Soc. China 33, 21-37.

Chen, J.S., 1978. A comparative study of the refraction and reflection seismic data obtained on the Changhua Plain to the Peikang Shelf, Taiwan. Petrol. Geol. Taiwan 15, 199-217.

Chen, Y.G., Liu, T.K., 1991. Radiocarbon dates of river terraces along the lower Tahanchi, northern Taiwan: their tectonic and geomorphic implications. J. Geol. Soc. China 34, 337-347.

Chesworth, W., 1973. The parent rock effect on the genesis of soil. Geoderma 10, 215-225.

Deffontaines, B., Lacombe, O., Angelier, J., Chu, H.T., Mouthereau, F., Lee, C.T., Deramond, J., Lee, J.F., Yu, M.S., Liew, P.M., 1997. Quaternary transfer faulting in the Taiwan Foothills: evidence from a multisource approach. Tectonophysics 274, 61-82.

Delcaillau, B., 2001. Geomorphic response to growing fault-related folds: example from the foothills of central Taiwan. Geodin. Acta $14,265-287$.

Delcaillau, B., Deffontaines, B., Floissac, L., Angelier, J., Deramond, J., Souquet, P., Chu, H.T., Lee, J.F., 1998. Morphotectonic evidence from lateral propagation of an active frontal fold; Pakuashan anticline, foothills of Taiwan. Geomorphology 24, 263-290.

Gee, G.W., Bauder, J.W., 1986. Particle-size analysis. In: Klut, A. (Ed.), Methods of Soil Analysis: Part 1. Physical and Mineralogical Methods. Agronomy Monograph, vol. 9. ASA and SSSA, Madison, WI, pp. 383-411.

Gile, L.H., Peterson, F.F., Grossman, R.B., 1966. Morphological and genetic sequences of carbonate accumulations in desert soils. Soil Sci. 101, 347-360.

Harden, J.W., 1982. A quantitative index of soil development from field descriptions, examples from a chronosequence in Central California. Geoderma 28, 1-28. 
Harden, J.W., Taylor, E.M., 1983. A quantitative comparison of soil development in four climatic regimes. Quat. Res. 20, 342-359.

Ho, C.S., 1988. An Introduction to the Geology of Taiwan: Explanatory Text of the Geologic Map of Taiwan, 2nd ed. Central Geologic Survey, Taiwan, Republic of China.

Hsiao, P.T., 1968. Seismic study of the Taichung area, Taiwan. Petrol. Geol. Taiwan 6, 209-216.

ISSS Working Group WRB, 1998. World reference bases for soil resource: introduction. In: Deckers, J.A., Nachtergaele, F.O., Spaargaren, O.C. (Eds.), 1st ed. International Society of Soil Science, International Soil Reference and Information Centre (ISRIC), and Food and Agriculture Organization (FAO). Acco, Leuven.

Jenny, H., 1941. Factors in Soil Formation. McGraw-Hill, New York.

Kao, H., Chen, W.P., 2000. The Chi-chi earthquake sequence: active out-of-sequence thrust faulting in Taiwan. Science 288, 2346-2349.

Leamy, M.L., Milne, J.D.G., Pullar, W.A., Bruce, J.G., 1973. Paleopedology and stratigraphy in the New Zealand Quaternary succession. N. Z. J. Geol. Geophys. 16, 723-744.

Lee, J.C., Lu, C.Y., Chu, H.T., Delcaillau, B., Angelier, J., Deffontaines, B., 1996. Active deformation and paleostressanalysis in the Pakua anticline area, western Taiwan. Terrestr. Atmos. Ocean. Sci. 7, 431-446.

Liew, P.M., 1988. Quaternary stratigraphy in western Taiwan: Palynological correlation. Proc. Geol. Soc. China 31, 169-180.

Liew, P.M., Hsieh, M.L., 2000. Late Holocene (2 ka) sea level, river discharge and climate interrelationship in the Taiwan region. J. Asian Earth Sci. 18, 499-505.

Liew, P.M., Huang, S.Y., 1994. Pollen analysis and their paleoclimatic implication in the middle Pleistocene lake deposits of the Ilan district, northeastern Taiwan. J. Geol. Soc. China 37, 115-124.

Lin, C.C., 1957. Topography of Taiwan. Publ. of the Taiwan Provincial Documentary Committee. (in Chinese).

Lu, C.Y., Jeng, F.S., Chang, K.J., Jian, W.T., 1998. Impact of basement high on the structure and kinematics of the western Taiwan thrust wedge: Insights from sandbox models. Terrestr. Atmos. Ocean. Sci. 9, 533-550.

Maejima, Y., Nagatsuka, S., Higashi, T., 2002. Application of crystallinity ratio of free iron for dating soils developed on the raised coral reef terraces of Kikai and Minami-Daito islands, southwest Japan. Quat. Res. (Daiyonki-Kenkyu) 41, 485-493.

MacFadden, L.D., Hendricks, D.M., 1985. Changes in the content and composition of pedogenic iron oxyhydroxides in a chronosequence of soils in southern California. Quat. Res. 23, 189-204.

McKeague, J.A., Day, J.H., 1966. Dithionite and oxalate extractable Fe and $\mathrm{Al}$ as acids in different various classes of soils. Can. J. Soil Sci. 46, 13-22.

McLean, E.O., 1982. Soil PH and lime requirement. In: Page, A.L., Miller, R.H., Keeney, D.R. (Eds.), Methods of Soil Analysis: Part 2. Chemical and Microbiological Properties. . Agronomy Monograph, vol. 9. ASA and SSSA, Madison, WI, pp. 199-224.

Mehra, O.P., Jackson, M.L., 1960. Iron oxides removed from soils and clays by a dithionite-citrate system buffered with sodium bicarbonate. Clays Clay Miner. 7, 317-327.

Morrison, R.B., 1968. Means of time-stratigraphic division and longdistance correlation of Quaternary successions. In: Morrison, R.B., WrightJr. Jr., H.E. (Eds.), Means of Correlation of Quaternary Successions. Int. Assoc. Quat. Res., VII Congress., Proc., vol. 8, pp. $1-113$

Mouthereau, F., Lacombe, O., Deffontaines, B., Angelier, J., Chu, H.T., Lee, C.T., 1999. Quaternary transfer faulting and belt front deformation at Pakuashan (Western Taiwan). Tectonics 18, 215-230.
Mulcahy, M.J., Churchward, H.M., 1973. Quaternary environments and soils in Australia. Soil Sci. 116, 156-169.

Nagatsuka, S., 1972. Studies on genesis and classification of soils in warm-temperate region of Southwest Japan: Part 3. Some features in distribution and mode of existence of free iron and aluminum oxides in the soil profile. Soil Sci. Plant Nutr. 18, 147-154.

Nelson, D.W., Sommers, L.E., 1982. Total carbon, organic carbon, and organic matter. In: Page, A.L., Miller, R.H., Keeney, D.R. (Eds.), Methods of Soil Analysis: Part 2. Chemical and Microbiological Properties. Agronomy Monograph, vol. 9. ASA and SSSA, Madison WI, pp. 539-577.

Ota, Y., Shyu, B.H., Chen, Y.G., Hsieh, M.L., 2002. Deformation and age of fluvial terraces south of the Choushui River, central Taiwan, and their tectonic implications. West. Pac. Earth Sci. 2, 251-260.

Reisenauer, H.M., 1982. Chromium. In: Page, A.L., Miller, R.H., Keeney, D.R. (Eds.), Methods of Soil Analysis: Part 2. Chemical and Microbiological Properties. Agronomy Monograph, vol. 9. ASA and SSSA, Madison, WI, pp. 337-346.

Rhoades, J.D., 1982. Cation exchangeable capacity. In: Page, A.L., Miller, R.H., Keeney, D.R. (Eds.), Methods of Soil Analysis: Part 2. Chemical and Microbiological Properties. Agronomy Monograph, vol. 9. ASA and SSSA, Madison, WI, pp. 149-157.

Rockwell, T.K., Kellar, E.A., Clark, M.N., Johnson, D.L., 1984. Chronology and rates of faulting of Ventura River terraces, California. Bull. Geol. Soc. Am. 5, 1466-1474.

Saldaña, A., Stein, A., Zinck, J.A., 1998. Spatial variability of soil properties at different scales within three terraces of the Henares River (Spain). Catena 33, 139-153.

Seno, T., Stein, S., Gripp, A.E., 1993. A mode for the motion of the Philippine Sea plate consistent with NUVEL-1 and geological data. J. Geolphys. Res. 98, 17941-17948.

Shih, T.T., Yang, G.S., 1985. The active faults and geomorphic surfaces of Pakua Tableland in Taiwan. Geographical Research of National Taiwan Normal University, vol. 11, pp. 173-186.

Soil Survey Staff, 1993. Examination and description of soils in the field. Soil Survey Manual, Handbook No. 18. USDA-SCS, Washington, D.C., pp. 56-196.

Soil Survey Staff, 2003. Keys to Soil Taxonomy, 9th ed. USDANRCS, Washington, DC.

Sung, Q.C., Chen, Y.C., 2004. Geomorphic evidence and kinematic model for Quaternary transfer faulting of the Pakuashan anticline, Central Taiwan. J. Asian Earth Sci. 24, 389-404.

Suppe, J., 1981. Mechanics of mountain building in Taiwan. Mem. Geol. Soc. China 4, 67-89.

Teng, L.S., 1987. Stratigraphy records of the late Cenozoic Penglai orogeny of Taiwan. Acta Geol. Taiwan 25, 205-224.

Tomida, 1932. The landscape on the southern Pakua Hill, Geomorphic memorandum of Taiwan 3, 3 (in Japanese).

Torrent, J., Schwertmann, U., Schulze, D.J., 1980. Iron oxide mineralogy of some soils of two river terrace sequences in Spain. Geoderma 23, 191-208.

Torrent, J., Schwertmann, U., Fechter, H., Alferez, F., 1983. Quantitative relationship between soil color and hematite content. Soil Sci. 136, 354-358.

Tsai, H., Sung, Q.C., 2000. A discussion on the origin of terrace scarp in southern Pakua tableland, Taiwan. Bull. Geogr. Soc. China in Taipei 28, 239-253 (in Chinese).

Tsai, H., Huang, W.S., Hseu, Z.Y., Chen, Z.S., 2006. A river terrace soil chronosequence of the Pakua tableland in Taiwan. Soil Sci. 171, 167-179.

Tsai, Y.B., 1986. Seismotectonics of Taiwan. Tectonophysics 125, $17-38$. 
Tseng, M.H., Liew, P.M., Chi, W.R., Shih, T.S., 1992. Pollen analysis of the Tananwan formation, northern Taiwan. J. Geol. Soc. China $35,247-259$.

Vreeken, W.J., 1975. Principal kinds of chronosequences and their significance in soil history. J. Soil Sci. 26, 378-394.

Wang, C.Y., Kuo, S.Y., Shyu, W.L., Hsiao, J.W., 2003. Investigating near-surface structures under the Changhua fault, west-central
Taiwan by the reflection seismic method. Terr. Atmos. Ocean. Sci. 14, 343-367.

Yu, S.B., Chen, H.Y., Kuo, L.C., 1997. Velocity field of GPS stations in the Taiwan area. Tectonophysics 274, 41-59. 